\title{
ANALYSIS OF INJECTION SYSTEMS TYPES USED IN AGRICULTURAL MACHINES
}

\author{
Sławomir Juściński, Wiesław Piekarski, Zdzisław Chomik \\ Department of Power Industry and Transport Means, University of Life Sciences in Lublin \\ "Corresponding author: e-mail: slawomir.juscinski@up.lublin.pl
}

\begin{tabular}{|c|c|}
\hline ARTICLE INFO & ABSTRACT \\
\hline $\begin{array}{l}\text { Article history: } \\
\text { Received: February } 2017 \\
\text { Received in the revised form: } \\
\text { May } 2017 \\
\text { Accepted: June } 2017 \\
\end{array}$ & $\begin{array}{l}\text { The paper presents analysis of the processes taking place in fuel } \\
\text { systems which lead to damage of injection devices in farm machines. } \\
\text { The most frequent reasons of failure of traditional injection systems } \\
\text { and Common Rail high pressure systems which are caused inter alia } \\
\text { by an improper quality of diesel oil were described and discussed. }\end{array}$ \\
\hline $\begin{array}{l}\text { Key words: } \\
\text { injection system, } \\
\text { farm tractors, } \\
\text { exploitation, } \\
\text { fuel quality, } \\
\text { wear }\end{array}$ & $\begin{array}{l}\text { Microscopic tests of the surface of worn plungers of the plunger and } \\
\text { barrel assemby of Motorpal injection pumps used in Zetor tractors } \\
\text { were carried out. Types of damage to elements of the injection pump } \\
\text { and electromagnetic injectors used in Common Rail systems CP4 type } \\
\text { based on the tests on the group of } 126 \text { on-site repairs were assessed. } \\
\text { Repairs were made in the repair centres in Podkarpackie Voivodeship } \\
\text { and centres dealing with repair of injection systems. Metallographic } \\
\text { tests were carried out in the Laboratory of Materials of Rzeszow } \\
\text { University of Technology with the use of electrone scanning micro- } \\
\text { scope Hitachi S-3400N. }\end{array}$ \\
\hline
\end{tabular}

\section{Introduction}

Foreign concerns and domestic producers of farm vehicles and machines have built a modern infrastructure which includes a network of authorized trader and repair centres representatives in Poland within the last two centuries. Ensuring by the general distributor and dealers professional technical service of products concerning surveys and repairs (Juściński, 2012; Juściński and Chomik, 2016; Juściński and Piekarski, 2010) is a basic standard in this network. The above actions are necessary due to a continuing progress concerning structural solutions and technologies of production of units and repair service systems of farm vehicles and they result from the research and development works as well as scientific research (Klimkiewicz, 2005a, 2005b, 2008; Michalski et al., 2014, 2015).

Modern agricultural vehicles are equipped with self-ignition engines which have modern technical solutions including high pressure common rail fuel injection systems. The common rail injection system has to optimize the fuel supply to cylinders with regard to the parameters of the amount and form which ensure the best course of the combustion process. The European Parliament and the American Agency for Environmental Protection succes- 
sively confirm new versions of standards where they define admissible values of emission of hazardous substances. Emission levels are varied depending on the type and power of the engine. Meeting the fumes emission standard IV/Tier4 due to high reduction of admissible value of hazardous substances emission - $\mathrm{NO}_{\mathrm{x}}$ oxides and solid particles, was a great challenge for producers of tractors and self-propelled farm machines. The operation of the fuel injection system, which is fit with regard to technical and exploitation issues, depends on the operation of the injection pump or in-line pump distributor. In case of improper fuel pump operation, in particular of injection parameters, the course of the process of forming fuel and air mixture and at the same time the engine operation are disturbed (Graba et al., 2010; Hetmańczyk et al., 2013; Kowalski, 2012; Kowalski et al., 2011). Symptoms of incorrect operation or damage to the fuel pump are as follows: decrease of power at the increase of the engine loading, irregular operation of the engine and the fact that another restart is impossible.

Factors which have a negative impact on those processes are as follows:

- high pressures operation,

- operation of variables and high temperatures,

- chemical influence of combustion products,

- phenomena which cause or impede erosive consumption (including cavitation erosion).

Friction processes have a significant impact on the course of consumption in exploitation of farm tractors. Tribological processes which take place in the places of a mobile contact of solid bodies depend inter alia on parameters of the cooperating surfaces and smearing of mobile units. Friction also occurs in supply systems which due to their structure and complex operation, high thermal and mechanical loading take a specific course. The injection apparatus consist of the engine unit which among main systems: a piston crank, timing gear, smearing, cooling and starting systems, is the most vulnerable to damage, therefore its participation is prevailing in repairs. In the structures of fuel systems of farm tractors, two types of injection pumps were used: section and distributor ones. Traditional fuel systems with injection pumps with mechanical regulators are replaced by electronically controlled systems. Common Rail high pressure injection systems producing pressure exceeding $200 \mathrm{MPa}$ cooperate with electromagnetic and piezoelectric injectors made by: Bosch, Delphi, Denso, Continental (Simens). Negative changes take place during exploitation both in macro and micro-geometry of material on the surface of working precision pairs, therefore there is a need of research in this field.

\section{Methodology of research}

Tests with the use of documentation of repairs were carried out in three establishments in Podkarpackie Voivodeship which deal with authorized repair of the injection apparatus. The tests included a representative group of 126 repair services made between 2015 and 2016. Metalographic tests with a scanning electrone microscope were carried out. They included consumption of the injection apparatus on the example of precision pairs of row pumps. Tests of injectors with the use of a digital microscope for particular types of wear were carried out. A statistical assessment of damages of elements of the injection pump and electromagnetic injectors used in Common Rail systems CP4 type used in Massey Ferguson tractors was performed. 


\section{Research results}

Metalographic microscope tests were carried out for the plunger and barrel assembly from the multi-sectional injection pump with combined sections. The micro-structure of the plunge and barrel assembly was tested including the groove controlling the fuel dose. Motorpal plunge used in Zetor tractor after 3000 motohours was the object of investigation.

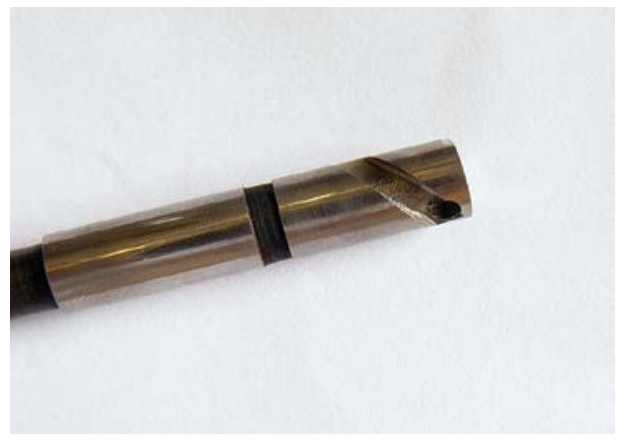

Figure 1. Plunger from Motorpal pump of Zetor tractor after 3000 motohours of operation

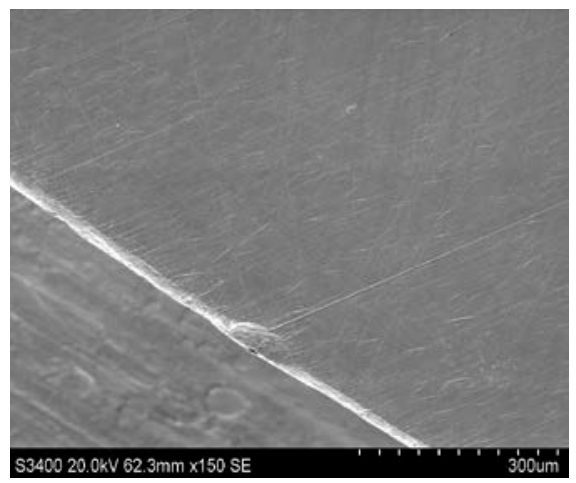

Figure 3. Plunger enlarged $150 x$ with a view on the groove controlling fuel dose

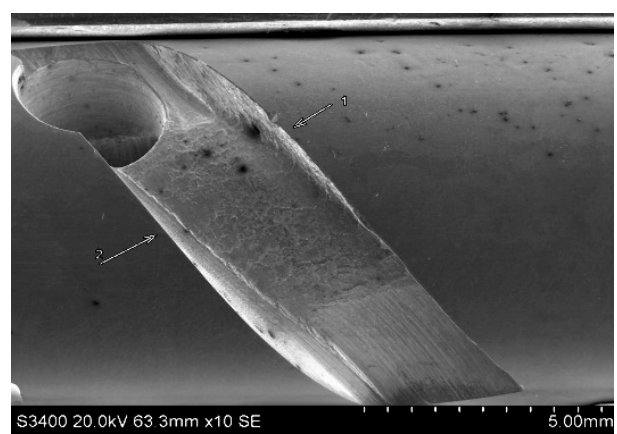

Figure 2. Plunger enlarged $10 x$ with a view on the groove controlling fuel dose

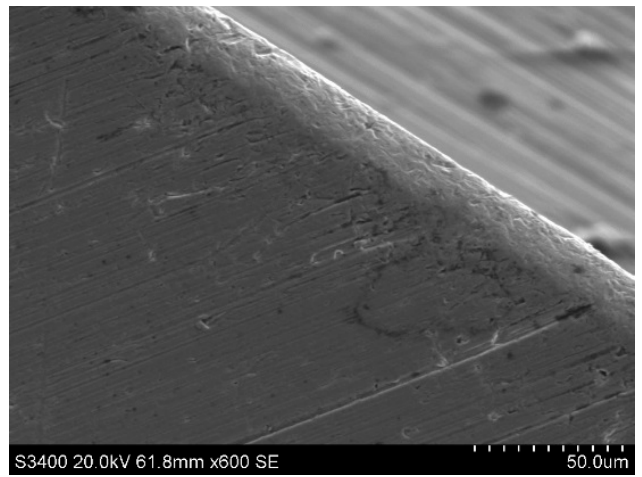

Figure 4. Piston enlarged $600 x$ with a view on the groove controlling fuel dose

Metalographic tests were carried out in the Laboratory of Materials of Rzeszów University of Technology with the use of a scanning electrone microscope Hitachi S-3400N which is designed for testing the morphology of the surface of solid bodies. Research was carried out with the use of enlargement: 10x, 150x, and 600x. Figures 1-4 present research results. The wear of the plunger in the area of the groove which controls the fuel dose was reported. Numerous indentations and pits were observed. Adsorption phenomenon and accumulation of carbon deposit and waxes which cause irregularity of fuel doses and decrease the tight- 
ness of the plunger and barrel assembly was reported. Metalographic images show the effects of friction wear and chemical corrosion as a result of the surface oxidation of metal. Figure 5 and 6 shows places where intensive consumption of elements during exploitation takes place in the DPA injection pump by CAV.

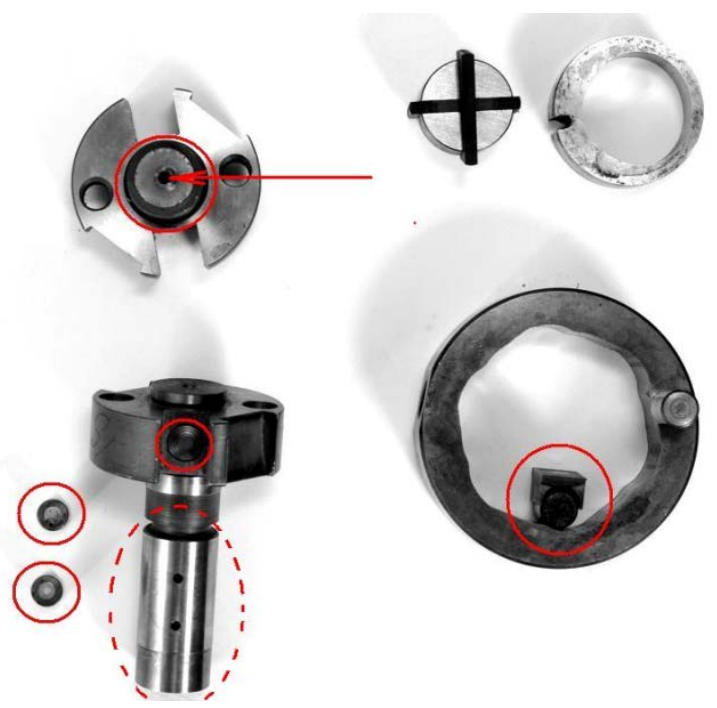

Figure 5. Selected elements of the injection pump DPA by CAV which are subject to intensive wear during exploitation

Figure 6. Rotational distributor of DPA injection pump by CAV with indicated spots of intense wear during exploitation

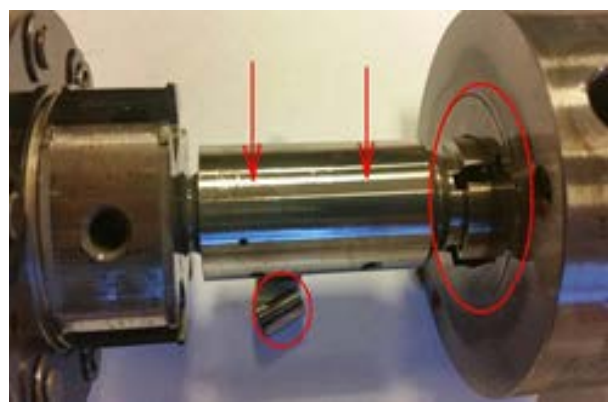

Analysis of documentation of technological processes performed during 126 repairs and information obtained in the form of a direct survey with employees of the repair department enabled estimation of the percentage participation of damages of particular elements of Common Rail type CP4 injection pumps. The highest level of damages was reported in case of a pump pressure controller and working elements namely pump pressure valves. Damages of the supplying pump or other damages, e.g. wear of the camshaft in the pump was considerably less often (Fig. 7). 
Analysis of injection systems...

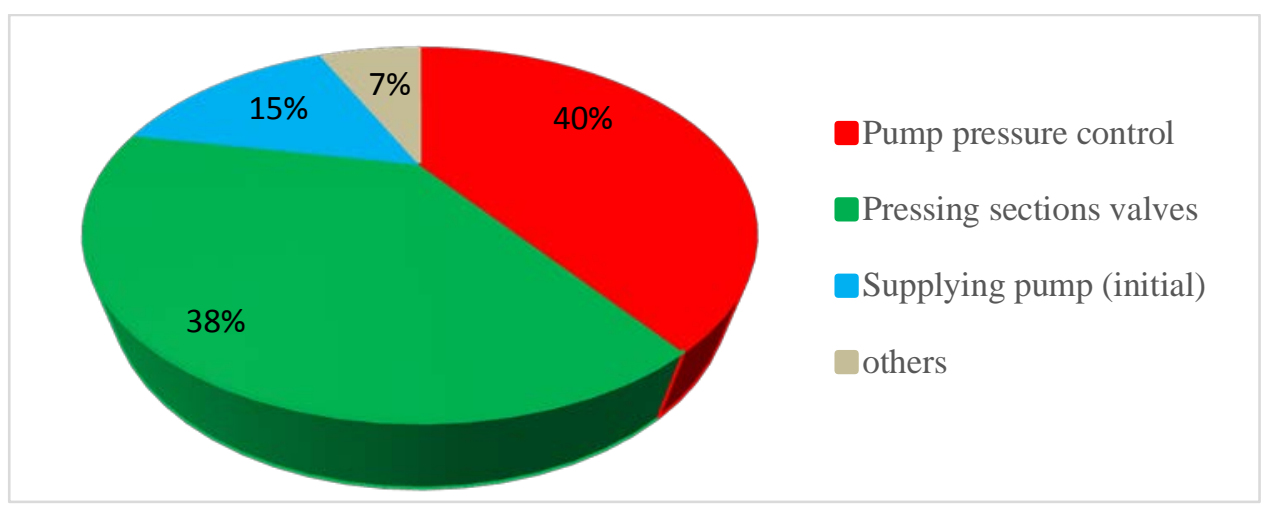

Figure 7. Distribution of particular damages of elements in the injection pump Common Rail type CP4 used in farm tractors

Injectors are the most impermanent elements of the Common Rail injection system, which directly influence the engine performance, capacity, fuel consumption and emission of hazardous oxides to atmosphere. Their consumption is related to direct impact of the pulsation pressure of $200 \mathrm{MPa}$ and thermal loading. The highest level of damages was reported for the needle valve, sprayers and control valves (Fig. 8).

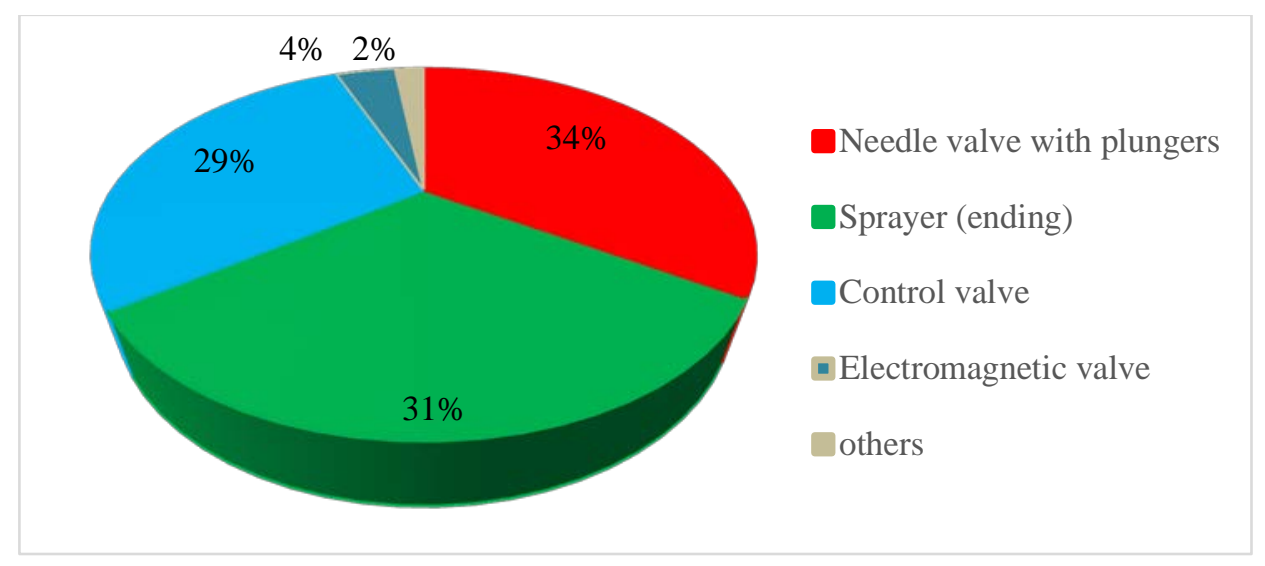

Figure 8. Participation of particular damages in electromagentic injectors used in the high pressure Common Rail systems 
Sławomir Juściński, Wiesław Piekarski, Zdzisław Chomik

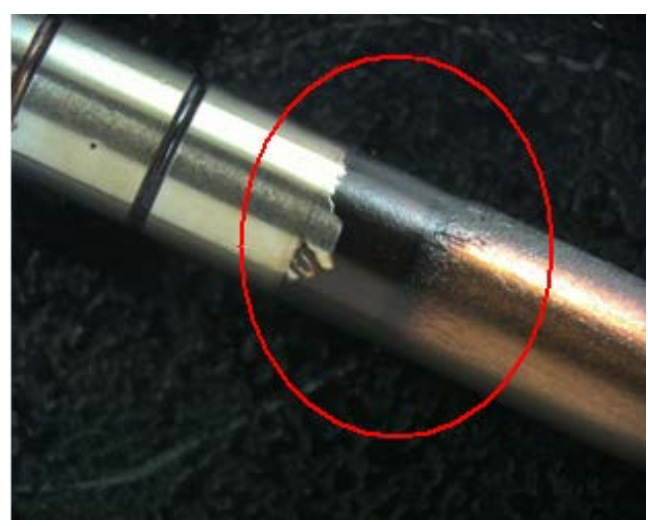

Figure 9. Corrosion pits on the knife-edge follower from Common Rail -Bosch sprayer

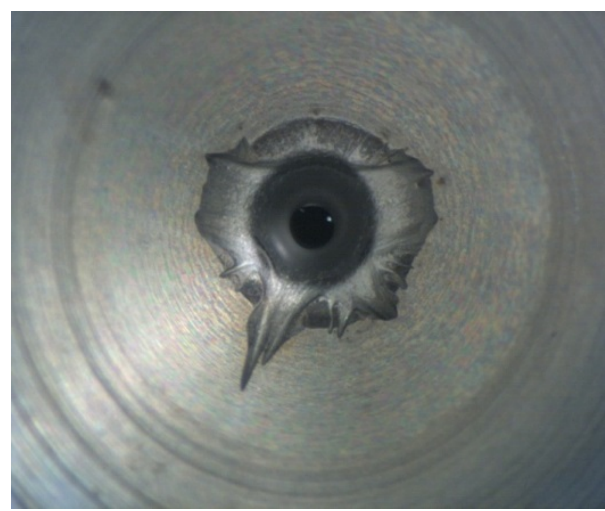

Figure 11. Damage to the control valve set of Common Rail-Bosch

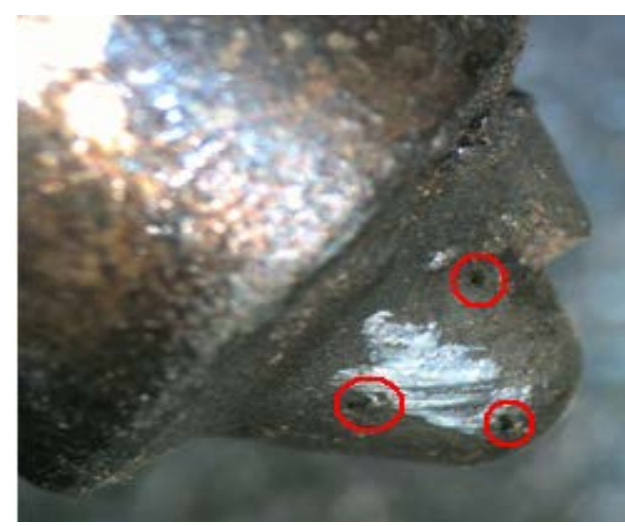

Figure 10. Overheating and change of the structure of the Common Rail-Bosch sprayer ending

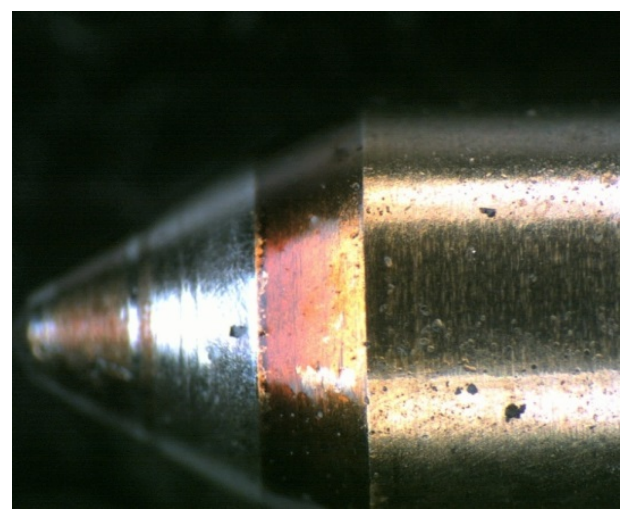

Figure 12. Corrosion pits and the change in the shape of the Common Rail-Bosch sprayer cone

Microscopic images of advanced changes in the condition of the cone surface of the needle and seat were made with a digital microscope Optical Smart with a specialist fibreoptic lighting (Fig. 9-12).

Yellow coating visible on the surface of the needle valve of the sprayer results from application of biofuels and influence of organic acids included in fuel. 


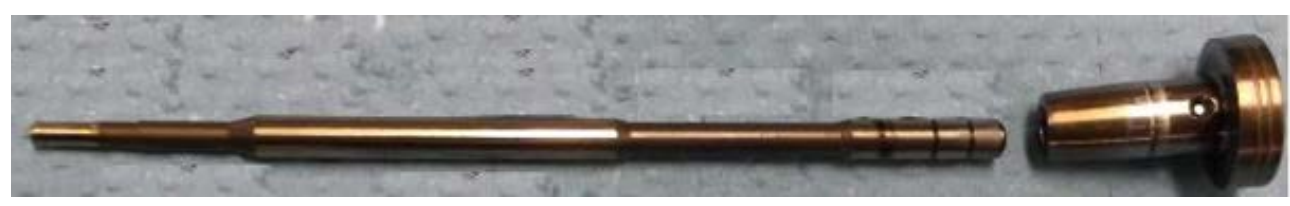

Figure 13. Wear of the surface of the needle valve of Common Rail injector

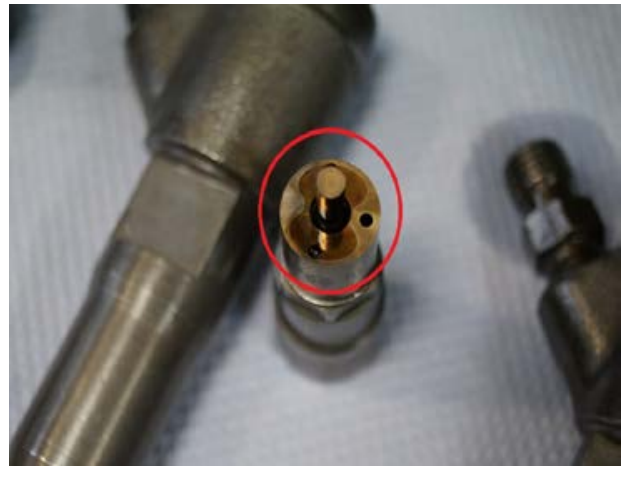

Figure 14. Corrosion pits on the injector sprayer which occurred affected by sulphur and water compounds in fuel

Source: firma Gładysek

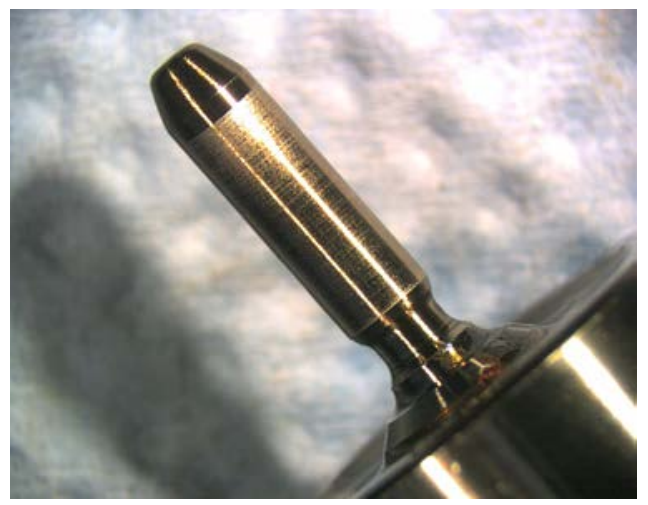

Figure 16. Friction and corrosion wear of the control valve piston (Common Rail)

Source: firma Gładysek

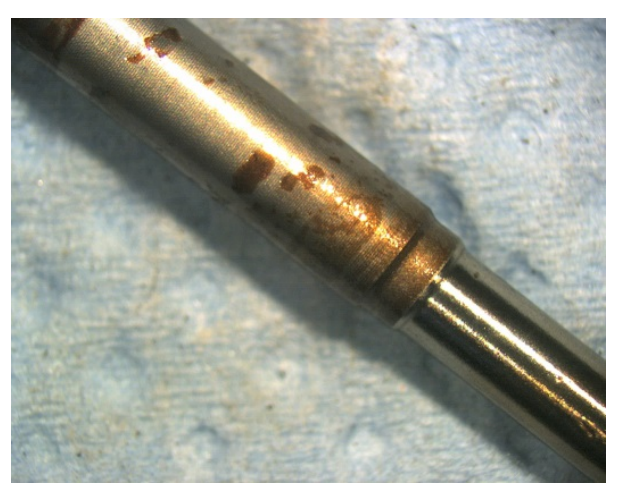

Figure 15. Corrosion pits on the needle which affected by sulphur and water compounds in fuel

Source: firma Gladysek

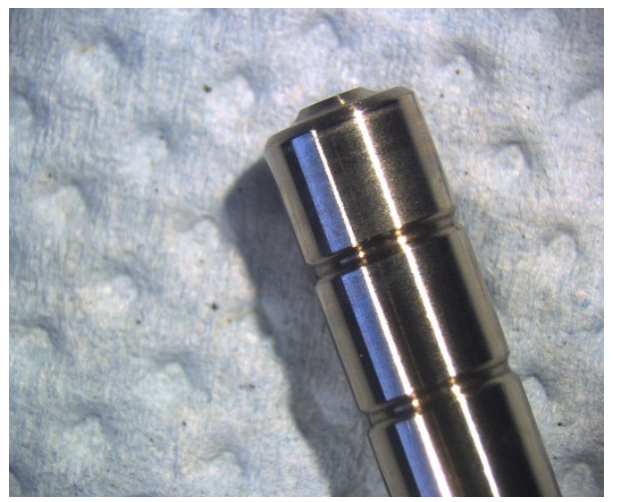

Figure 17. Fricton and corrosion wear of the knife-edge follower (Common Rail).

Source: firma Gladysek 
The tests which were carried out on components of the injection system confirmed that the wear of the surface of elements as a result of friction and corrosion is a frequent phenomenon (Fig. 9-17). This type of damage occurs in the plunger and barrel assembly although these elements are adjusted, smeared and cooled. Sprayers exposed to the simultaneous impact of several factors (pressure, temperature, combustion processes) and the socalled cavitation erosion work in particularly difficult conditions. Endings were often blocked with coke which disturbed the process of fuel injection. The problem occurs particularly in case of diesel oil with addition of fatty acids methyl esters (FAME) used as biocomponents (Czechlowski et al., 2006; Dzieniszewski, 2008; Klimkiewicz et al., 2013).

\section{Conclusions}

During the use of farm vehicles, various processes of destruction of the technical condition of particular units take place. Intensity of their wear and tear depends on the structure, conditions of exploitation and the manner of use. A technical condition in the period of exploitation depends also on the proper selection of exploitation materials and correct repair operations with maintaining the type specification and time periods recommended by the producer (Natke and Cempel 2012; Rybacki et al., 2013; Rzeźnik, 2008; Rzeźnik et al., 2015). Tests on the repair of injection high pressure systems confirm that the condition of malfunction and fault occur very often within this scope. Damages and faults are usually related to improper features of the used fuel and particularly with the level of permanent contamination. PN-EN 590/2013 standard determines an admissible value of solid impurities at the maximum level of $24 \mathrm{mg} \cdot \mathrm{kg}^{-1}$ of fuel. It should be emphasised that this level of contamination is applicable from the moment the traditional injection systems are used. Presence of mineral and organic impurities is a result of improper realization of refining, transport and distribution of diesel oil processes. Diesel oil may also contain water in the fixed (emulsion) and non-fixed form. Water in the free form is produced as a result of temperature changes and the process of condensation and this leads to corrosion damages. Fuel filters constitute protection against contamination but only if they are replaced on a regular basis. Two-stage fuel filters: initial $10 \mu \mathrm{m}$ and the final one $2 \mu \mathrm{m}$ with water and heavier impurities separator are used in the engine of e.g. John Deere 6R equipped with the Common Rail fuel injection system. Modern fuel filters are efficient at the level of over $98 \%$ for particles with the diameter of $2-4 \mu \mathrm{m}$.

The research and analysis of results enable formulation of conclusions:

- Metalographic tests with the scanning electrone microscope on the wear of injection apparatus on the example of the plunger and barrel assembly of the injection pump proved occurrence of pits and micro-indentations and wax substances which influence the quality and precision of measurement of subsequent fuel doses.

- Assessment of the types of damage to the elements of the injection pump and electromagnetic injectors used in Common Rail type CP\$ systems proved that the highest number of damages is related to the pump pressure control and pressure valves and in case of electromagnetic injectors needle valves, sprayers and control valves were damaged the most often.

- Based on the research it may be said that the reason of fault of the elements of the injection system consisted in improper quality of the used fuel: the increased water content 
which causes corrosion and chemical or solid impurities which lead to friction wear or seizing up of elements which touch fuel. Information obtained in the direct survey with employees of the repair departments allow the statement that vehicle users who are responsible for irregularities related to service, no regular replacement of fuel filters and using fuel which does not meet quality standards cause faults of the fuel systems.

\section{References}

Czechlowski, M., Krysztofiak, A., Adamski, M. Antczak, W. (2006). Wpływ stosowania oleju rzepakowego jako paliwa na trwałość układu wtrysku w silnikach ZS. Agricultural Engineering, 12(87), 85-92.

Dzieniszewski, G. (2008). Wybrane problemy stosowania biopaliw do zasilania silników z zapłonem samoczynnym. Inżynieria Rolnicza, 10(108), 39-45.

Graba, M., Lechowicz, A., Mamala, J., Bieniek, A. (2010). Wielofazowy wtrysk paliwa dla silników z zapłonem samoczynnym wyposażonych w rzędową pompę wtryskową. Agricultural Engineering, 5(123), 29-35.

Hetmańczyk, I., Hepner, W., Halicki, R. (2013). Modyfikacja charakterystyki zewnętrznej silnika o zapłonie samoczynnym poprzez zmianę parametrów wtrysku paliwa. Agricultural Engineering, 2(143), 79-89.

Juściński, S. (2012). Analiza struktury zapotrzebowania na przeglądy techniczne podczas eksploatacji pojazdów rolniczych, Annals of Warsaw University of Life Sciences - SGGW, Agricultural and Forest Engineering, 60, 119-127.

Juściński, S., Chomik, Z. (2016) Regeneracja w naprawie pojazdów rolniczych. Monografia naukowa, Towarzystwo Wydawnictw Naukowych Libropolis, Lublin, ISBN 978-83-63761-67-7.

Juściński, S., Piekarski, W. (2010). The farm vehicles operation in the aspect of the structure of demand for maintenance inspections. Eksploatacja i Niezawodnosc - Maintenance and Reliability, 1(45), 59-68.

Klimkiewicz, M. (2008). Model neuronowy pozwalający zlokalizować usterki w pompach wtryskowych. Agricultural Engineering, 1(99), 159-164.

Klimkiewicz, M. (2005a). Zastosowanie sieci neuronowych do diagnostyki układu wtrysku paliwa w silnikach wysokoprężnych. Agricultural Engineering, 8(68), 153-160.

Klimkiewicz, M. (2005b). Zastosowanie zbiorów przybliżonych w diagnostyce układów wtryskowych silników wysokoprężnych. Agricultural Engineering, 14(74), 177-183.

Klimkiewicz, M., Mruk, R., Osiak, J., Roszkowski, H., Słoma, J., Wojdalski, J. (2013). Efektywność pracy silnika zasilanego olejem rzepakowym. Inżynieria Rolnicza, 2(143), 123-132.

Kowalski, D. (2012). Wpływ sterowania wtryskiem paliwa na drgania silnika ZS stosowanego w ciągniku rolniczym. Agricultural Engineering, 2(136), 129-138.

Kowalski, D., Graba M., Lechowicz A., Bieniek, A. (2011). Wpływ zastosowania wtrysku wielofazowego na przebieg ciśnienia spalania w cylindrze silnika ciągnika rolniczego. Agricultural Engineering, 5(130), 117-124.

Michalski, R., Arendt, R., Janulin, M., Gonera, J. (2014). Diagnostyka uszkodzeń ciagników kołowych. Identyfikacja relacji, modele, hardware i software systemu diagnostycznego. Olsztyn, Wyd. Uniwersytetu Warmińsko-Mazurskiego, ISBN 978-83-72999-08-5.

Michalski, R., Gonera, J., Janulin, M. (2015). A functional and task fault-oriented diagnostic system for wheeled tractors. Agricultural Engineering, 3(155), 59-68.

Natke, H.G., Cempel. C. (2012). Model-aided diagnosis of mechanical systems: Fundamentals, Detection, Localization, Assessment. Springer Science \& Business Media, ISBN 978-3-64264395-8. 
Sławomir Juściński, Wiesław Piekarski, Zdzisław Chomik

Rybacki, P., Rzeźnik, C. Durczak, K. (2013). Logika diagnostyki w ocenie stanu technicznego nowoczesnych ciągników rolniczych. Agricultural Engineering, 4(147), 271-279.

Rzeźnik, C. (2008). Podstawy obstugi technicznej maszyn rolniczych. Wydawnictwo Akademii Rolniczej w Poznaniu, ISBN 978-83-71-60485-0.

Rzeźnik, C., Durczak, K., Rybacki, P (2015). Serwis techniczny maszyn rolniczych. Wydawnictwo Uniwersytetu Przyrodniczego w Poznaniu, ISBN 978-83-7160-788-2.

\title{
ANALIZA RODZAJÓW USZKODZEŃ UKŁADÓW WTRYSKOWYCH STOSOWANYCH W POJAZDACH ROLNICZYCH
}

\begin{abstract}
Streszczenie. Praca przedstawia analizę procesów zachodzących w układach paliwowych, które prowadzą do uszkodzeń aparatury wtryskowej pojazdów rolniczych. Opisano i omówiono najczęściej występujące w eksploatacji przyczyny niezdatności układów wtryskowych konwencjonalnych i wysoko ciśnieniowych Common Rail, spowodowane m.in. niewłaściwą jakością oleju napędowego. Przeprowadzono badania mikroskopowe powierzchni zużytych tłoczków par tłoczących pomp wtryskowych Motorpal stosowanych w ciągnikach Zetor. Dokonano oceny rodzajów uszkodzeń elementów pompy wtryskowej i wtryskiwaczy elektromagnetycznych stosowanych w systemach Common Rail typ CP4 na podstawie badań grupy 126 napraw warsztatowych. Miejscem badań były firmy serwisowe prowadzace działalność na terenie województwa podkarpackiego oraz firmy zajmujace się naprawa układów wtryskowych. Badania metalograficzne wykonano w Laboratorium Materiałów Politechniki Rzeszowskiej z zastosowaniem mikroskopu elektronowego skaningowego Hitachi S-3400N.
\end{abstract}

Słowa kluczowe: układ wtryskowy, ciągnik rolniczy, eksploatacja, jakość paliwa, zużycie 